\title{
POLIS KAVRAMI
}

Yazan: Prof. Sübeyp DERBIL

İdare Hukukunda polis (= zabıta) kavramı oldukça bulanık kalmıştır. Ahmet Şuayp ve Roger Bonnard gibi birtakım hukukçular, bulanuklıktan söz açarak polis kavramını sınırlamağa, belirli bir çerçeve içine alarak aydınlatmağa çalışıışlardıt [1]. Felix Moreau ve Maurice Hauriou gibi birtakım hukukçular ise bu kavramı sınırlamak taraflısı olmamışIar, ona çok geniş, pek kaplamlı mânalar vermişlerdir. Moreau'ya göre: kanun vaz'1, nizamname tanzimi, askerlik mükellefiyeti, ticaret şirketlerinin esas mukavelenamelerini neşretmek mecburiyetleri, merkezsizleştirme rejimine tâbi idari teşkilât üzerinde merkez teşkilâtının kontrol hakkı (ki Moreau buna kidarî vesayec» diyor), diplomatların ve orduların d1şardan gelecek saldırışlara karşı memleketi korumaları gibi işler bile polis anlamı içindedir $\left.\underline{[}^{2}\right]$.

Profesör Hauriou polisi o kadar geniş bir mânada kabul ediyorki ona göre: Devletin hedefi polistir. Polisi temin için, Devlet umumi kaideler (kanunlar ve nizamlar) vazederek yasak olan ve olmayan şeyleri bildirir. Bildirmek yetişmez, bu kaidelerin icrasını da temin etmelidir. Icra ise ya adlî veya idarî yollarla olur. Adlî yol, hâkim tarafından ceza müeyyedelerinin tatbikidir. Idarî usulde, yurttaşların kanuriları istekleriyle saymaları, kamusal hizmetlerle güven altına alınır. Idarî teşkilàtın hedefi, böylece, kanunlanın tatbikinden, yani Polisten ibarettir.

Modern Devletlerin umumi polisleri ilk öğretimin yayılmasını gerekli gördügüünden, ilk ögretimin mecburi olması için kanunlar vazedilmiş bulunmaktadır. Ancak, bu kanunların tatbiki için kazai müeyyideler kâfi değildir. Bu işte hususi okullara bel bağlamak istenilmediğinden ilk

[1] Aahmet Suayp, Hulkuku İdare, Itstanbul 1326 (1910), sahife 367; Roger Bomnard,

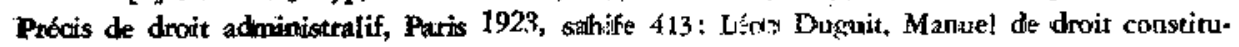
onnel, Patis 1923, sahife 106 v. s.

[2] Felix Moceau, Manuel de drodt pubdc, Paris 1909, cilt II sahife 70-72 
ögrretim kamusal hizmetini kurmak gerekmiştir. Bu sebeple, ilk öğretim kamusal hizmeti, ilk öğretim mecburiyeti kanuntunun polis vasıtasıdır [ 3 ].

Hauriou'ya göre Devletin «tevsil»» işlerinde de polis vazife ve salâhiyetleti vardır: para basmak, darphane açmak hakkı; fabrika ve ticaret markalarını ve ünvanların tescil ve temin etmek hakkı; ölçüleri kontrol etmek hakka; hususi hukuka taalluk eden muameleleri notetier ve borsalar gibi vasitalarla tescil ettirmek hakkı; fertlerin medeni hailerini nüfus kürügüne geçirmek hakkı; gayri menkullerin parçalarınt, sahiplerini, alınup satılmasın, devrini, rehnini gösteren kadastro ve tapu kayıtları yürütmek hakkı; imtihan etmek ve diploma vermek hakk1.... hep birer polistir.

Profesör Hauriou, polis anlamını o kadar geniş tutmuştur ki içtimai muavenet (prévoyence sociale) işlerinde bile bir polis hedefi görmektedir.

Moreau ve Hautiou gibi hukukģuların polis kavramın bu kadar geniş tutmamalarının taribî sebepleri vardır. Eski devirlerde plois anlami pek genişti: Kamusal idare polis demekti. Eski Yunancada kent (=belde = cité) demek olan «polis», mânasınt genişleterek kent reşkilâtr, devlet teşkilâtı, Devlet idaresi, hüküimet manâlanına da gelmeğe başlamış; ve Lâtince de siyası teşkilât, kamusal idare anlamlarmı da ifade $\left[^{1}\right]$ ettikten sonra on dördüncï asırda Fransız hukuk dilinde «poliss) kelimesi Devletin ve Devlet faaliyetinin hedeflerini ifade etmek için, dar manâda da düzenliği, iyi düzenlenmiş bir Devleti vasıflandırmak üzere kullanılmuştır. On beşinci asır sonunda Aimanya bu Fransız kavramın olduğu gibi benimsemiştir $\left[^{5}\right]$. O sıralarda kamusal düzenliğgi korumak kaygısı, kamusal hizmetleri yaymak kaygıssndan çok üstïn olduğu için polis, her türlï Devlet faaliyetlerini tazammun eden geniş mânasını muhafaza ediyordu. On yedinci astrda başta adliye olmak üzere haricî politika faaliyei, asketî işler ve maliye idaresi diğer Devle işlerinden ayırdedilmeğe ve polis kavramının dışında sayılmağa başladı.

Fransız ihcilâli polise esash tahditler vazetmiştir. Ferdî hürriyetleri belli eden ve koruyan 1791 beyannamesini, polis anlamın belirtmeğe

["] Maurice Hauriou, Préxis de docic admintstratif et de droint pulblic, Fantis 1921, 445

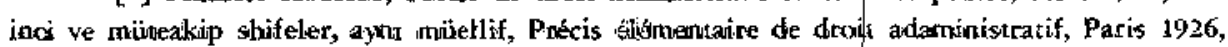
212 inci ve snïreakip shlhifeler.

["] Hengi Capitant, Vocatoulaire jurique, Paris, sahife 376

["] Fnizz Fleiner, Les principes gatnéteaux du droit administratif aflemand, Paris 1933,

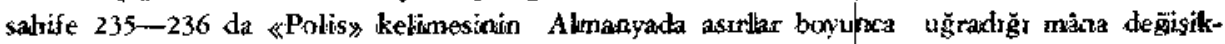
Iiklenini anlatryor. 
yaramıyacağı için, bir yana burakalım. Dördïłncia yılın «Suçlar ve cezalar kanunus (Code des délits et des penes) bu baxumdan pex deǵeru bir vesikadir. Bu kanunun 16 inc maddesi diyorki "polis kamusai duzenlikie ferdî hürriyet, taşarruf ve güvenliği korumak için tesis edıłniştır.») Modern Devletlerde polisin rolü böyıece belismeğe başlamuştır.

Polis kavramın belirli bir çerçeve içinde sımrlamak yolunu tutan bukuçular arasında da çok büyük kavrayıs tarkları göze çarpıyor. Bilhassa Türk hukukçulariyle birtakım Fransız hukukçuarı pe aykırı neticelere vasıl olmuşlardır. Îdare Hukukumuzun en değerli kurucusu olan Ibrahim Hakkı (Paşa) şöyle diyor: «Hüikümeti icraıyenin asayiş ve istirahati umumiyeyi ve ahalinin hukuku medeniye ve tsartufiyeleriyle can ve malca emniyetlerini muhafazaya memur olan kismuna zabıta «Polis» itlâk olunur.» [']. Ísmail Hakkx (Göreli) şu tarifi ileri sürüyor: «Zabıta. tâbiri dahilen emniyet ve asayişin temin ve muhafazast zımnında vücuda getirilen teşkilâtın heyeti mecmuasını ifade eder.» [ $[7]$

Her iki hukukçůnuzun fikirlerine göre polis idarî teşkilât mânasın tazammun etmektedit. Fransiz hukukçularindan Duguit ve Bonnard'a göre ise polis hukuki tasarruf, idarî tedbir mânalarını tazammun etmektedir. Duguit diyorki: «Polịs, otorite tarafından ferdî faaliyetlerin serbest gelişmelerini önleyici bir surette tahdit eden bir tasarrufu (acte) tazammun eder (içerir).» [ $\left.{ }^{8}\right]$ Roger Bonnard'a göre Polis tâbiriyle «dirginliği, gävenliği ve sağlığı korumak maksadiyle, fertlerin härriyetlerine ve tasarruf haklarına ilişmek üzere, idarî otoriteler tarafından umumi veya ferdî şekilde alınan müeyyideli tedbirlerì almak lâzunodirr $\left[{ }^{\theta}\right]$.

Hangisi doğru? Polis bir idari teşkilâtmıdır? Yoksa birtakım hukuki tasarruflar ve idari tedbirler midir? Ne Türk hukukçularının, ne de Fransız hukukçularının fikirleri yanlış sayılabilir. Esasen birbirine uymayan iki fikirden birisinin mutlaka yanlış olması gerekmez. Böyle fikirler çok kere birbirlerini bütünleyebilir. Biri meselenin bir cephesini, öteki diğer bir cehpesini aydınlatabilir. Tek bir fikre saplanı kyalnız bu vardir ») demek her zaman doğru olmaz; «bu da vardır.» demek daha yerinde olabilir. Böyle bir zihniyet karşımıza çıkan meseleleri her vecheden kavramamıza yardımi olabilit. Nitekim burada Türk hukukçularının

['] 1bathim Hakkx, Huktik Jdane, Istulbul 1312 (1896), oil + I, schile 168,

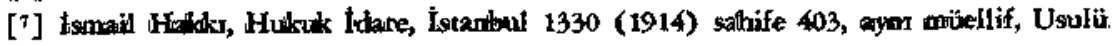
Idare ve Kavanin, Istambul 1341 (1925), shife 127.

[8] Duguit, ynlaxinda söbeñ geçen eseni, sahife 106.

[9] Roger Bonnand, Prtócis de dogit adminisuratif, Patris 1926, sahife 397. 
fikirleriyle Fransız hukukçularının fikirleri birbirlecini bütünlemektedir. Hakıkatte, polis tâbıri ıaare hukukunda iki mânada kullanılmaktadır:

1 - Idarî teşkilât (dirginliği, guvenliği ve sağhı̆ı korumak maksadiyle vücuda getirılen idarî teşkılarj: Unitornali polis, atiı polis, sivil polis, motorlu polis sözlerinde olduğu gibi.

2 - İdarî tedbirler ve hukukı tasartuflar (dirginliği, güvenliği ve sağlığı korumak maksadiyle alınan idarî tedbirler, vazolunan kanunlar, nizamlar hürriyet tahditleri) : basın polisi, âyin polisi, cemiyetler polisi, toplanma polisi, saglık polisi sözlerinde olduğu gibi ki «polis rejimi» tâbiri altunda toplantr.

İbrahim Hakkı ve İsmail Hakkının izahları polis tâbirinin birinci mânasını, Duguit ve Bonnard'n izahlanı ise ikinci mânasını aydınlatmaktadır. Yusuf Nuri ve Berthélemy polisin bu iki mânasın bir arada mütalâa etmişlerdir. Yusuf Nuri: «Polis kelimesi dahili memlekette intizam ve sıhhatin muhafazası için teşkil edilne hidemat veyahut münasip görülen tedabirin heyeti mecmuasın ifade eder.» (10) diyor. Berthélemy de: «Polis tâbiri, memlekec içinde düzenliği, güvenliğ ve salğı̆̆ı temin etmek için teşkil edilen hidematın veya alınan tedbìlerin heyeti mecmuastm ifade eder. $\left.{ }^{[1}{ }^{1}\right]$ demekle Yusuf Nurinin fikrine tamamen uygun bir kavrayıs belirtmektedir.

Böylece, modern anlamda polis, yalnız şu iki kavramı içermektedir. (tazammun etmektedir):

1 - İdarî teşkilât.

2 - İdarî tedbirler ve hukuki tasarruflar.

Şu kadarki, her türlii idarî teşkilât, her türlii idarî tedbirler, hürriyet tahdicleri ve hukuki casarruflar polis sayilamaz. Ancak ve yalniz kamusal dirginliği, güvenliği ve sağlı̆ga korumak maksadiyle vüicuda getirilen idarî teşkilất, alınan idarî tedbirler, vazolunan hürriyet tahdit. leti ve yapılan hukuki tasarruflar polis anlamı içine girer. Görülüyorki, polis anlamını belirli bir çerçeve ile sınırlayabilmek için «maksat» unsuru çok önemli bir ölçü (critérium) rolü oynamaktadır. O halde gereği gibi bir analiz yapabilmek için:
A) Polis rejimini,
B) Polis maksadınt,
C) Polis teşkilâtını, Kısaca gözden geçirmeliyiz.

A) Polis rejimi. - Hepimizin hürriyetini korumak için, her birimi-

[10] Yusulf Nuri, Halkuku Idtare, lotaciboxil 1325 (1909), cilt II, sadvife I.

[11] Berulúleurry, Trainé êlêtmentaire de droit administratil, Paris 1933, sahife 267. 
zin hürriyetletini tahdit eden kanun, kamusal idareye, hukuka aykurı hareketlerin ve hâdiselerin önüne geçmek için böyle bir hareket veya hâdise baş göstermeden tedbir almak vazife ve salâhiyetini vermiş bulunmaktadir.

Kusuriyle birisini çiğneyip sakatladığı veya ölümüne sebep olduğu takdirde cezalandırılması şartiyle her kesin istediği gibi otomobil kullanabilmesi hürriyet ve hukuk rejimi icabıdur. Bir kimsenin otomobil altında çiğnenmesi hukuka aykırı bir hâdisedir. Bu çeşit hukuka aykırı hâdiselerin önüne geçmek için birtakım polis tedbirleri alınmıştır. Resmû şofölrük ehliyetnamesi olmayanlar otomobil idare edemezler; otomobiller kamusal idare tarafñdan ilân edilmiş belirli bir süratten fazla huzla sevk edilmemelidir; yolun sağından sevk edilmelidir; gece fenersiz sevk edilmemelidir vesaire.... Bir kimse resmî şoförlüik ehliyetnamesi olmadı$\breve{g}_{1}$ halde yollarda otomobil kullanursa veya otomobili yolun solundan sevk ederse cezaya çarpılır. Dikkat edilecek olursa ehliyetnamesi olmayan bir kimsenin otomobil kullanması hukuka aykırı bir hâdise değildir: bu hareketiyle hiç kimsenin hukukuna tecavüz etmemiş, kimseye zarar vermemiş olabilit. Işte hị kimsenin hakkına bir tecavïz teşkil etmediği halde birtakım hareketlerin - güvenliği, dirginliği veya sağlığı korumak maksadiyle - yasak edilmesi ve cezalandırılması polis rejimi icabıdtr.

Teşkilâtı Esasiye Kanunumuz: «Her Türk hür doğar, hür yaşar. Hürriyet baskasına muzir olmıyacak her türlü tasarrufatta bulunmaktır. Hukuku tabiiyeden olan hürriyetin herkes için hududu başkalarının hudut hürriyetidir. Bu hudut, ancak kanun marifetiyle tespit ve tâyin edilir.ss diyor.

Devletin mukavele ile kurulmuş bir varlık olduğunu ileri sürenler, mukavelenin akdi șrasında fertlerin hürriyetlerini şart koştuklanın b:1dirmişlerdir. Fert, mukaveleye muvafakatini bildirdikte, gneiş istiklâlinden vazgeçmiş, ancak bazı haklarını muhafaza etmiş imiş. Rousseau, Locke, Wolff bu düşüncede idiler $\left[^{12}\right]$.

[12] «Fentletion muclak is riklâli.... bütrin roplubakkandian önce var olan bir hal, bir hareket noktası saydryondu. Birlikne yaprlan bir mukavele ile devlet kunmak içio jnsanilar illk ge-

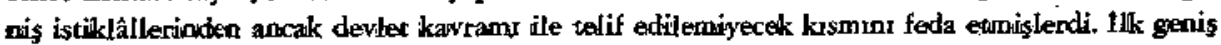

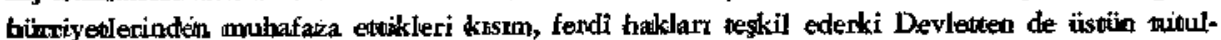

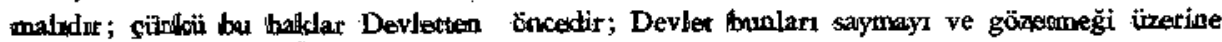
almistur. Iste Lodke, Woiff, Blackkstone, bizzat Rousean ve nishayer Sieyes ve daha bir colklarn tarafmdan ileri sïriälen çok iyri kur ulmu, gok binerli karsam (theorie) bu idi.y

(A. Esimein, Elléments de droit constiautionnelle, Paris 1921, oilt. I, sahife 541)

Hukak rejimi ve polis rejimi halkkinda Loowa iDuguit, traitue de droit constitutionnel, Paris 1930, cilt IIJ, sahifee 649-654 dee daha etraflt izahatlar vardir. 
Bunlar anlaşılmaz ve gereksiz düşüncelerdir. Hürriyetlerin tahditlerine hangi yandan bakulırsa bakılsın, şu üç noktayı kabul etmek yerinde olur:

1 - Insan, tabiat iktizasi, hürdïr; miş olur;

2 - Insanın hürriyeti, topluluk içinde bulunmakla, tahdit edil-

3 - Tabii hürriyetimizin tahdidi, ancak topluluk için gerektiği kadar olursa itiraz götürmez.

1 - İnsanın tabï olarak hür bluunduğunu kavramak için ilk insanların nasıl olduklarını uzun boylu araştırmak istemez. Yalnız başına insan tasarlanamaz. Tabii insan topluluk içinde yaşayan insandır. Ancak, dilediğimizi yapmamiza engel olan kanunların ve nizamların da tabî̀ olduğunu akıl kabul etmez. Kanun ve nizam sun'i şeylerdir ve vücut bulabilmek için ilerlemiş bir medeniyet muhiti lâzımdır. Bundan dolayı, kamusal hürriyetlerin topluluk tarafından fertlere bağışlandığı kabul edilemez. Hürriyet, dilediğini yapmak tabii; bunun tahdidi ise ancak sun'i olabilir. Teşkilâtı Esasiye Kanunumuz «Her Türk hür doğar, hür vaşar.»» Demekle bu düşünceyi telkin ve teyit etmektedir.

2 - Topluluk bïrriyetlerimizi tabdit etmiștìr. Illk çăg devletlexi uzun boylu düşünmemişlerdir: topluluğun bir varlık, hem de çok önemli bir varlık olduğunu görünce, topluluk dışında bir şey tanımamışlardır. Topluluk karşssında fertler silinmiştir. Eski ças̆ ulusları, Devletin kanunlarla fertlerin canlarına, mallanına, hürriyetlerine, hattâ vicdanlarına hâkim olabileceğinde şüphe etmemişlerdi. Ferdî hak ve hürriyet düşüncesi birtakım mütefekkirlerin zihninde ş̧ıldanamış değildi. Bu düşüncelerini ortaya attıkları için birkaç yiğit mütefekkire baldıran otu suyu içirildiğini biliyoruz.

Eski çağda ferdî háklar düşüncesi felsefe ülkesinde kaldı, hukuk älisesine girmedi, devlet kuruluşunda kendine bir yer edinmedi. Eski çă devletleri kanun yapmak, ordulara kumanda ckmek, adaleti tevzi eylemek, vergi toplamak ve vicdanlara el uzatmakta devam etti. Devletlerin resmî tanrıları, âyinleri, mabetleri ve yine resmî rahipleri vardı. Bunları mağlûplara, kanunlariyle birlikte zorla kabul ettizirlerdi.

Şu eski çă̆ anlayıß̧ı yeni çağın mutlakiyet taraflıtarından da görülï: yor. Meselâ, Bossuet: «Kıralın salâhiyetlerini ancak Tanrının iradesi tahdit edebilir» diyor. Bu halde hürriyet nerede kalır? Kıralın keyfî harekețerine, haksızlıklarına karşı ne yapılabilir? Tanıının iradesi kıralın salâhiyetini ne dereceye kadar tahdit etmiştir? Tanı, fertlerin hürriyetini; kıralın ne dereceye kadar gözetmesini irade etmiş̧ir? Bunlar belli değil- 
dir. Bu anlayışa göre, hürriyet, ancak kıralın tebeasına bir lûtfu gibi görünüyor. Bu yanlıs düşünce bize büyük bir hakikati gösteriyor. $O$ da şuqur:

Her yerde ve her zamanda uluslar, nasil bir Devlet kurmuş bulunurlatsa bulunsunlar, hürriyetlerini adım, adım, uğraşa, uğraşa kazanmışlardir.

3 - Tabii bürriyetin tabdidi, ancak kamusal dirginlik için gerektiğ i kadar olmalıdır. Bu tahdidin sınırını kurumsal (=tnéorique) olarak belirtmenin yolu bulunmamıştır. Bu sınır zamana göre, memlekete göre, anlayışa göre değişir. Birtakım insanlax, halka bırakılan hürriyetin kötü kullanilmasından doğacak tedirgindikleri, iyi kullanılmasından doğacal. faydalardan üstün görürler. Bu gıbi kimseler, güvenlik ve dirğinlik ig̣i . de yaşamak için hürriyetin feda edilmesini isterler. Birtakım inşanlar ise, belki de hiç kullanmadıkları ve kullanmayacakları bir hürriyetin kalkmasinda müthiş bir istibdat görürler. Bunlara göre istibdat bir yıkımdır, güvenliği, dirginliği hürriyete feda etmelidir.

$\mathbf{O}$ halde ne yapmalı? kimlerin dediğini dinlemeli? kimlerin isteḱlerini yerine getirmeli?

Topluluğun bu günkü ileri yaşayışında polis rejimine yer vermen menin imkânı yoktur. Hürriyeti tabî̀ genişliğinde tutmak için hukuka aykırı hareketlerin ve hâdiselerin baş göstermesini beklemek, baş gösterince faillrini cezalandırmak, topluluk içinde yaşamayı dayanılamıyacak kadar güç ve sikıntılı bir hale sokar.

Polis rejimnden vazgeçilemeyince, bu rejime ne gibi yerlerde baş vurmalıdır? Polis rejimine en çok aşğaıdaki yerlerde ve işlerde ihtiyaç vardir:

a) Umumi yollarda ve yerlerde, yani herkesin gidip geldiği, girip çıktığı yerlerde sıkı bir polis rejïmi gereklidir. Bu gibi yerlerdeki polis rejimi herkesin hürriyetini ve güvenliğini korumak içindir.

Hiç kimse: «Şu dört yol ağzında polis memuru arabaların gelip gitmelerine ne diye karışyyor? ne hakla arabaları durduruyor veya yol veriyor? niçin arabaların yaya kaldırımı üzerine çıkmaları yasak edilmiştir? ’s diyemez.

b) Zecr ve tazmin sistemine dayanan bukuk rejiminin içtimai ve ferdî zararları silmeğe yetişmediği işłerde de polis rejimi gözetilmelidir. Eğer bir hareket veya hâdiseden doğacak kötülük onarılamıyacak kadar büyükse bu gibi hareketlerin ve hâdiselerin önüne polis rejimi ile geçmek yerinde olur. Hürriyet bu yüzden tahdit edilecektir. Ancak, bu tahditten kimse şikâyet edemez; çünkü yapılan tahdit çok büyük kötülükleri önlemek içindir. 
Meselâ: ölüm, yangın gibi hâdiseleri önlemek için silâh taşıma. yasağı, şehir içinde barut, petrol gibi patlayıı, yanıcı ş̧eyler depo etmek yasagı çok yerındedir. «Niçin silâh taşımak serbest değil? niçin komşum isterse evini benzinle veya barutle dolduramasın? niçin bu hürriyetler tahdit edilsin?s) demek çok saçma olur. Bu gibi hürriyetlerler yüzünden baş gösterebilecek ölüm veya yangın o kadar büyük birer kötülüktürki bunlardan topluluğu korumak için konulan yasakları herkes beğenir.

c) Sağlık işlerinde de polis rejimi ne kadar sıkı olsa yeridir. Kolera, veba, tifo, kızıl, çiçek gibi salgın hastalıkların yayılmaması için tutulanların kordon altına alınması, tutulmayanların aşılanması tedbirlerinde gereksiz birer hüriryet tahdidi görmek kadar yanliş bir düşünce olamaz.

Sağhlk işlerinde, hürriyet yüzünden baş gösterebilecek kötülükler o kadar çok o kadar büyüktürki hususi yerlerde ve evlerde bile kamusal idarenin buna karışması kimseyi sızlandırmamalıdır.

Ancak, polis rejimi keyfî bir rejim demek değildir. Polis rejimini, hukuk rejimi gibi bir kanuni rejim halinde bulundurmak gerektir. Kamusal idare, ancak kanunla muayỹen hallerde ve muayyen şekillere, şartlara uygun surette müdahale edebilmelidir ki polis rejimi ezici bir rejim ofmasın. Türk âmme hukuku polis rejiminin kanuni bir rejim olmasını ister.

B) Polis maksad. - Polis, topluluk içinde dirginliği, güvenliği ve sağlı̆̆ korumak içindir. Polis maksatları bunlardır.

Dirginlik, kargaşalık olmaması demektir. Topluluk içinde tabiî hal budur. «Herkes işinde, gücünde.» derler; yani yollarda, umumi yerlerde gïrülttii, patırdı, kavga, bağırma, toplanma gibi uygunsuzluklar yok demektir. Dirginliğe «Kamusal düzenlik» (=ordre public) de derler [ $\left[{ }^{13}\right]$

Bugünkü devletlerin korumağa çalıstrkları dirginlik özdeksel (= maddi) düzenliktir. Tinsel (= mânevi) dirgirlik gözetilmez. Profesör Hauriou bu noktayı çok güzel açıklıyor. Diyorki: «Polis için dïzensizlik uyandıran her şey yasak edilmeğe, hiç dïzensizlik uyandırmayan her şey de kayırılmağa veya serbest bırakılmağa değer. Ozdeksel düzensizlik polise yol gösteren bir belirtidir sttma hekime yol gösteren belirti

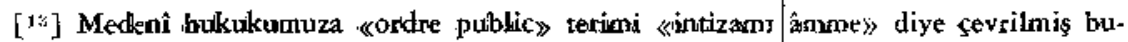
lonmaktadir. «Kaumusal düzenlik» deonek bana daha doğna görünülyor. Esaslı bu terimin hususi bukuktaki anlamı idare tułkukundaki ankammdan başkadur. Hasusi hukukta bir hukui kaide hakkında: «intizamr âmme kaidesidir.» Denildimi hosusi mokavelederle büyłle bir kaideye aykiri antașmalar yaptlatmaz demektir. 
olduğu gibi ve polis, hekim gibi, yalıız belirtiyi gidermeğe yarayacak bir tedavi tarzı kullanır; toplumsal (social=) kötürüğ̈̈n derin sebeplerine ulaşmak için uğraşıaz, özdeksel düzenliği, hattâ çok kere sadece sokaktaki düzenliği iade etmekle iktifa eder; başka bir tâbirle düşüncelerde ve duygulardaki tinsel düzenliği gözetlemez, tinsel düzensizlikleri aramaz, bu iş için kökünden yetkisizdir (=incompétent); buna kalkışırsa, mekanizmasının ağırlığı dolayisiyle, işi hemen enkizisiyona ve vicdanları stkmağa kadar vardırır.» [14]

Bununla beraber, polis özdeksel kargaşaltk doğuracak tinsel kargaşalıklarla da uğraşı ki ablâk polisi bu düşüunce ile yaratılmıştır $\left[^{1 \bar{a}}\right]$.

Güvenlik, insanlara ve eşyaya zarar getiren hâdiselerin ve hâdise ihtimallerinin yokluğu $\left[^{10} \mathrm{~J}\right.$ ile hasıl olur. Güvenliği kurmak ve yaşatmak için bu gibi hâdiselerin öniune geçilir.

Sağlrk, hastalık ve hastalık tehlikesinin yok $\left[{ }^{10}\right]$ olmasıdır. Ileri Devletler insanları, yollar, umumi yerleri, hususi yerleri, hayvanlan, nebatları, hattâ yiyecek ve içecekleti bu noktadan gözetmeği ïzerlerine almış bulunuyorlar. Bundan dolayı, sağlık polisi çok çeşitli işlerle yüklüidür: insanları, yapıları, yolları, hayvanları, nebatları gözetecektir. Bunun için dirginlik ve güvenlik işleriyle uğraşan polisten ayrı birtakım teşkilât vücuda getirilmiş, birçok kanunlar ve yasaklar vazoluñmuştur.

[14] Hquriou, өözü gegen eseri, sahife 445 .

[15] 4 temmuz 1934 tath ve 2559 numaralr «Polis vazife ve salâthityer kanumu»nun

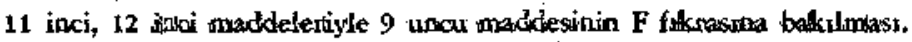

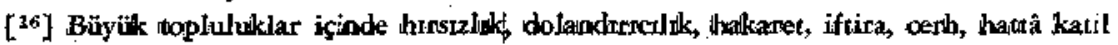
hâdiseleninin hiç olmamasım jonemek, hiç hastal olmamarsm isıemek gibuidir. Bö̈yle bix hal

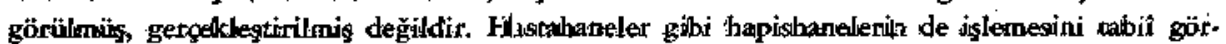

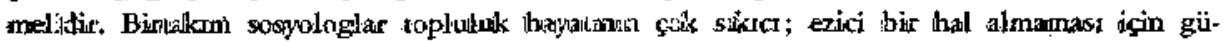

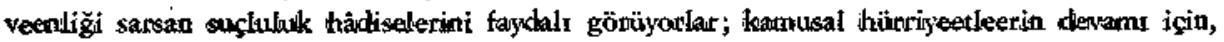

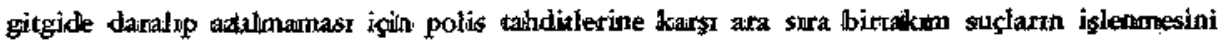
gerekli saywortar. Profesör Max Nordau'a göne asanlaur syimser bic yacatrisşcadyr. Nondau, bir

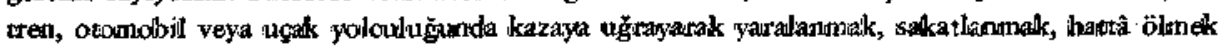

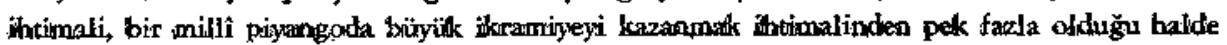
seve seve treme, otomobile veya azcăğa binmenizi ve piylango bileti almamaz içimize sinmis olan iyimsertak ile ipath ediyor.

thatimali thesapdanda on binde bir ihtitnal yok farzedilir. Moeelâ: bir totba digine 9999

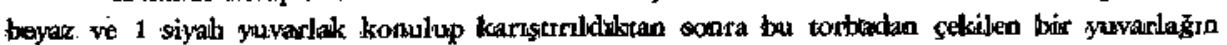

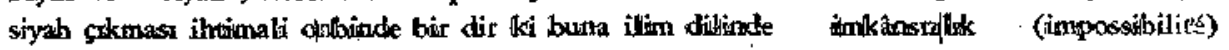
adr verilimelktediar.

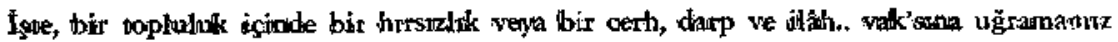

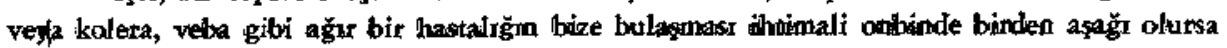
biz lbu ihtimali you farzeder ve tam bir girmenilik havasi iginde yasatr.r. 
Poliste maksat esash bir unsurdur. Hürriyet tahditlerinin, bir polis olabilmesi için dirginlik, gïvenlik veya sağlığı korumak niaksadiyle vazedilmiş bulunması şarttır. Böyle bir maksat gütmeyẹn tahdit veya tedbir polis sayılamaz.

Birkaç misal alalım:

10 nisan 1322 taribli asars atika nizamnamesinin 8 inci maddesine göre asarı atikayı zahire anbarı ittihaz etmek hapis ve para cezası tehdidiyle yasak edilmiştir. Bu hürriyet tahdidi bir polis değildir. Çünkü bu yasakta dirginlik, güvenlik yeya sağlı̆̆ı korumak maksatlarından biri yoktur.

20 haziran 1304 taribli gaz ve ispirto anbarına dair talimatın 5 inci maddesine göre dükkânlarda altı sandıktan fazla pecrol bulundurulması müsadere tehdidiyle yasak edilmiştir. Bu hürriyet tahdidi bir polistir. Cüinkï bu yasakta dirginlik ve güvenliği korumak maksadı vardır.

14 kânunusani 1943 tarih ve 4374 numaralı Barut ve patlayıcı maddeler silâh ve teferruatı insarı hakkındaki kanunda iki maksat seziliyor. Birincisi Devlete gelir kaynağı sağlamak maksadiyle vazolunan inhisar ki polis değildir. İkincisi barut ve barut gibi patlayıcı maddelerin tehlikeli yerlerde, tehlikeli ellerde bulunmamast kaygisı ki bu bir polistir. Çünkü güvenliği koruma maksadiyle vazolnumuş bir tahdittir $\left[{ }^{17}\right]$.

Birtakım vilâyetlerimizde kağnı yasak edilmiştir. Birçok şehirlerimizde otobillerin saatte 20 veya 30 kilometreden fazla hizla gitmeleri yasak edilmiştir. Bu yasaklardan birincisi polis değildir. Çünkü bu yasakta dirginlik, güvenlik veya sağlığı kroumak maksadı yoktur. Kagnılar yolları çabuk bozar; yolların çabuk bozulmaması için, yani bir polis maksadiyle değil ekonomi düşüncesiyle böyle bir yasak konulmuştur. Ilkinci yasak bir polistir. Otomobiller çok hrzlı yürütülürse çarpışmak veya adam çiğnemek tehlikeleti baş gösterir. İşte bu tehlikelere karşı güvenliği korumak için otomobillerin hızlı gitmesi yasak edilmmiştir.

Poliste maksadın esaslı bir unsur olmasından bir netice daha doğar; o da şudur:

Dirğinlik, güvenlik veya sağlığı korumak mkasadı olmadıç̧a alınan tedbirler, kanuni şekillere uygun olsalar bile, yolsuzdur; bilâkis dirğinlik güvenlik veya sağlı̆̆ı korumak maksađiyle salâhiyetli âmitler

[1i] Kaminưu 8 inci madkkesine bakrlimasi. 
tarafından alınan tedbirler - kanunda böyle bir tedbir alınabileceğine dair sarahat olmasa bile - yolundadır, kanunîdir.

Birkaç misal getirelim:

4 temmuz 1934 tarih ve 2559 numaralı Polis vazife ve salâhiyet kanununun 7 inci meddesi, bir yerde otel, gazino, kahve, içki yetleri, bar, tiyatro, sinama, hamam ve plâj gibi umuma mahsus istirahat ve eğlence yerlerinin açılmasını o yerin en büyük mlükiye âmirinin iznine bağlı tutmuştur. En büyük mülkiye âmixi izin verirse açılacak, izin vermezse açı. lamıyacatır. Bir sinema veya bar gibi eğlence yeri açmak üzere yapılı̧ı bir müracaatı, en büyük mülkiye âmiri, böyle eğlenceleri beğenmediği veya sevmediği için reddetmeğe kalkışırsa yolsuzluk etmiş olur. Eğer dirğinlik, güvenlik veya sağlik kaygısiyle reddederse yoliyle hareket etmiş olur.

Hiçbir kanunda, en büyük mülkiye âmirinin hususi bir şahsa ait sağlam bir evi, bedelini vermeden, hattâ krymet takdir ettirmeden yıkrrrabileceğine dair bir kayıt yoktur. Bilâkis, gerek Teşkilâtı Esasiye Kanunumuz, gerekse istimlâke mtaallik hukuki mevzuatımız böyle bir gayri menkulün bedeli önceden ödenmedikçe tasarruf edilemiyeleğini bildirmektedir [18].

Bu sbeple, her hangi bir vali veya kaymakam değeri biçilmemiş bir sağlam evi yıktırırsa kanuna aykırı hareket etmiş, hattâ suç işlemiş olur. Ancak, bir şehirde büyük bir yangın çıkar ve yangının önüne geçmek için birkaç evin yıkılmasından başka çare bulunmazsa, vali veya kaymakam bu evlerin hemen yıkılmasını emredebilir. Bu emir, bu karar yolsuz değildir. Güvenliği korumak maksadiyle alınmış bir polis tedbiridir. Bunun içindir ki 2559 numaral kanunun ikinci maddesinde şöyle bir fıkra vardır: «Polisin görecĕgi vazifelerde selâhiyetli âmirden verilecek emirlerde memurin kanununun $\mathbf{4 0}$ incı maddesi hükmü cari değildir.»

Memurin kanununun 40 incr maddesine göre: «Memur; emir, talimatname ve nizamname ve kanun hükümlerine mugayir olarak her hangi bir makam veya âmirinden bir emir telâkki edince onun ahkâma mugayeretini kendi âmirine bildirir. Âmiri israr edersè, metnur, bütün mesu-

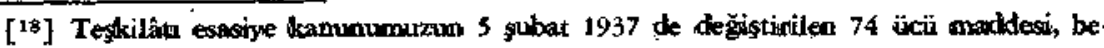

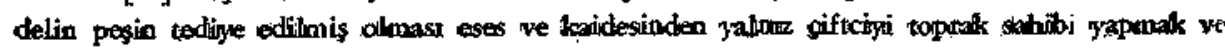

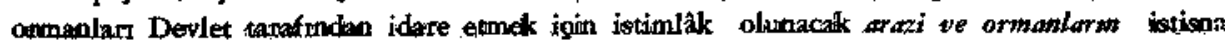

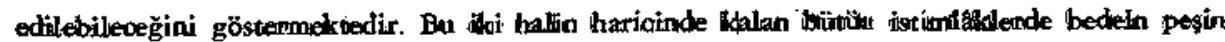
odanmesi prensibi devawn entmelkentir. 
liyetin kendi âmirine ait ve münhasır olduğunu tahriren bildirerek o emri infaz eder. Bu misillu emirlerin kanunen cürüm teşkil eden mevaddan bulunmaması lâzımdır. Aksi takdirde memur bu emri katiyen infaz etmez ve daha yüksek makama keyfiyeti bildirmeğe mecburdur.»

Dirğinlik ve güvenliği korumağa borçlu olan polisler hakkında memurin kanununun 40 incı maddesi hükümlerinin cari olması doğxu olamazdr. Çünkü güvenliği korumak için bazen kanuna muhalif, hattâ kanunen umumi olarak suç sayılan tedbirleri almak zarureti baş gösterébilit.

C) Polis teşkilất. - Kamusal idarenin belli başlı amaçlarından biri yurt içinde güvenliği, dirginliği ve sağlığı korumaktır. Hiçbir kamusal hizmet yokturki güvenliği veya sağlı̆̆ı korumağa yarar olmasın. Posta, telgraf işlerini veya maarif işlerini alalım; hepsinde - ikinci plânda olsa da - polis maksadı bulabiliriz. Bunun için Profesör Hauriou, polisi çok geniş anlamda kabul etmekle pek yanlış hareket etmiş sayılamaz.

Yalnız güvenliği ve dirginliği korumak için olan idare teşkilâtı bizde polisleri, jandarmaları ve bekçileri ihtiva etmektedir. Yalnız sağlı̆̆g korumak için olan teşkilât, insanların, bayvanların, nebatların sağlı̆̆ını koruduğuna göre Sıhhat ve Içtimai Muavenet vekâletini, Milli Müdafaa Vekâletini (kışlalarda sağlık, askerlerin sağlı̆̆ı), Ziraat Vekâletini (Hayvan sağlik polis, nebat hastalıklariyle mücadele...) Belediye idarelerini (Belediye kanununun 15 inci maddesi) ihtiva etmektedir.

Bizde potis, Emniyet teşkilâtı kanunumuza göre, silâhlı icra ve inzibat kuvveti olup üniformalı ve sivil olmak üzere iki kısimdır. Uniformalı polis vasitalı (atlı, bisikletli, motorlu vesaire...) ve vasıtasız kısımlara ayrilir.

Vilâyetlerde «Emniyet müdürü», kazalarda «Emniyet âmiri veya komiseri», merkezde «Emniyet Umum Müdürï» vardır.

Kanunlara, nizamnamelere, hükümet emirlerihe ve kamusal düzenliğe uygun olmayan trareketlerin işlenmesinden eyvel kanun dairesinde önünü almak polise dïser. Bu polisin idarî vazifesidir. Polisin bu idarî vazifesinden başka adli vazifesi de vardır. $O$ da işlenmiş olan bir suç hakkında ceza muhakemeleri usulï kanunu ile diğer kanunlar da yazılı işleri yapmaktır. Adli vazifesini yaparken polis adli otoritenin emrine tâbidir. 
Polise hem idari, hem adli vazifeler yükletilmesi Idare ve Adliye otoritelerinin ayrı olması prensibine aykırı düşmektedir.

Jandarma, 10 haziran 1930 tarih ve 1706 ntmaralı kanunla 1886, $2227,3148,3155$ numaralı eklerine göre güvenlliği ve.dirginliği korumağa memur silâhlı ve askerî bir inzibat kuvvetidir.

Jandarma, askerî talim ve terbiye işlerinde Genel Kurmay Başkanlığına, silâh ve mühimmatiyle seferberlik ve seferde ordu emrine geçeceklerin maaş, iaşe, ilbas ve teçhizatı ve bütün masrafları millî Müdafaa Vekâletine, güvenlik ve dirginlik işleriyle bütün diğer muamelelerde Dahileye Vekâletine bağlıdır.

Merkezde umum jandarma kumandant vardır ki Millî Müdafaa Vekilinin muvafakatı alınmak şartiyle Dahiliye Vekilinin inhası üzerinı Reisi Cumburun tasdikiyle tâyin olunur. Kolordu komutanı derecesindedir.

Jandarma miilki teşkilâta bağlıdır. Kadrolarını Dahiliye Vekâleti tertip eder. Jandarma subayları dirlik ve güvenliği korumak işlerinde mahallin en büyük mülkiye memurunun emri altındadır. Jandarma subaylari umumiyetle atlidir.

Jandarmalar, polisler gibi, suç işlerinde adli otoritenin emri altındadır. Dirğinlik ve güvenliği korumak şehirlerde, kasabalarda, iskele ve istasyonlarda umumiyetle polislere, şehir ve kasaba haricinde jandarmaya düşer.

Bekçiler polislerin ve jandarmanın yardımcısıdır. Çarşı ve mahalle bekçileri polise, kır bekçileri jandarmaya bağlıdır. Bekçilerin de adliye otoritesi emrine bağlılıkları vardır. 